\title{
Acute gastroenteritis: from guidelines to real life
}

This article was published in the following Dove Press journal:

Clinical and Experimental Gastroenterology

14 July 2010

Number of times this article has been viewed

\author{
Chung M Chow' \\ Alexander KC Leung ${ }^{2}$ \\ Kam L Hon' \\ 'Department of Paediatrics, \\ The Chinese University of \\ Hong Kong, Hong Kong Special \\ Administrative Region, PR China; \\ ${ }^{2}$ Department of Pediatrics, The \\ University of Calgary, Calgary, \\ Alberta, Canada
}

Correspondence: Chung M Chow Department of Paediatrics, 6/F Clinical Science Building, Prince of Wales Hospital, Shatin, Hong Kong Special Administrative Region, PR China

Tel +852 2632286 I

$\mathrm{Fax}+85226360020$

Email ccm250@ha.org.hk

\begin{abstract}
Acute gastroenteritis is a very common disease. It causes significant mortality in developing countries and significant economic burden to developed countries. Viruses are responsible for approximately $70 \%$ of episodes of acute gastroenteritis in children and rotavirus is one of the best studied of these viruses. Oral rehydration therapy is as effective as intravenous therapy in treating mild to moderate dehydration in acute gastroenteritis and is strongly recommended as the first line therapy. However, the oral rehydration solution is described as an underused simple solution. Vomiting is one of the main reasons to explain the underuse of oral rehydration therapy. Antiemetics are not routinely recommended in treating acute gastroenteritis, though they are still commonly prescribed. Ondansetron is one of the best studied antiemetics and its role in enhancing the compliance of oral rehydration therapy and decreasing the rate of hospitalization has been proved recently. The guidelines regarding the recommendation on antiemetics have been changed according to the evidence of these recent studies.
\end{abstract}

Keywords: gastroenteritis, vomiting, antiemetic, ondansetron, rotavirus, oral rehydration therapy, intravenous therapy, guideline

\section{Introduction}

Gastroenteritis is defined as the inflammation of the mucus membranes of the gastrointestinal tract and is characterized by diarrhea or vomiting. It is a common childhood disease. Children in developing countries are particular at risk of both morbidity and mortality. Worldwide, gastroenteritis affects 3 to 5 billion children each year, and accounts for 1.5 to 2.5 million deaths per year or $12 \%$ of all deaths among children less than 5 years of age. ${ }^{1-3}$ In developed countries, such as the United States, acute gastroenteritis seldom causes deaths, however, it still accounts for 300 deaths per year. $^{2}$ Moreover, it puts a heavy burden on the health care system. Acute gastroenteritis causes 1.5 million visits to primary care providers each year and 220,000 hospital admissions for children under the age of 5 years; that is $10 \%$ of all the hospital admissions of children in the United States. ${ }^{2}$ In general, developing countries have a higher rate of hospital admissions as compared to developed countries. In the United States, the admission rate is 9 per 1000 , per annum, for children younger than 5 years old. ${ }^{4}$ When compared to the United Kingdom and Australia, the admission rates are around 12 to 15 per 1000 per annum. ${ }^{5,6}$ However, the rate increases dramatically to 26 per 1000 per annum in China. ${ }^{7}$ This may be due to the facts that children in developed countries have a better nutrition status and better primary care. The difference can also be explained by the fact that, the incidence of acute gastroenteritis is significantly higher in developing countries than the industrialized countries. ${ }^{8}$ Interestingly, Hong Kong 
is a developed city, and yet the admission rate is even higher than many of the developing countries. ${ }^{9}$ This may reflect that the decision of admission does not simply depend on the clinical situations, but it can also be affected by the parents' wishes and other social factors.

\section{Etiology}

Viruses are the most important etiology and are responsible for approximately $70 \%$ of the episodes of acute gastroenteritis in children. ${ }^{10}$ There are over 20 different types of viruses that have been identified as etiological agents. ${ }^{11}$ Worldwide, rotavirus is still the most common virus causing this disease and accounts for some $30 \%$ to $72 \%$ of all the hospitalizations and $4 \%$ to $24 \%$ of acute gastroenteritis at the community level. ${ }^{12-15}$ Virtually all children have been infected with rotavirus by the age of 3 years. ${ }^{16}$ Rotavirus infection is seasonal in temperate climates, peaking in late winter, although it occurs throughout the year in the tropics. The peak age for infection ranges from 6 months to 2 years. Other common viruses causing gastroenteritis include calicivirus, adenovirus and astrovirus. Globally these viruses are responsible for diarrhea episodes in hospitalized children, with detection rates varying from $3.2 \%-29.3 \%, 1 \%-31 \%$, and $1.8 \%-16 \%$, respectively. ${ }^{17-20}$ Rates of virus infection are similar in both developed and less developed countries. ${ }^{21}$ Bacterial infection accounts for $10 \%$ to $20 \%$ of all the acute gastroenteritis. ${ }^{22}$ The most common bacterial causes are, Salmonella species, Campylobacter species, Shigella species and Yersina species. Vibrio cholerae remains a major cause of diarrhea, especially after a disaster where sanitation is compromised. Giardia lamblia is the most common protozoal infection that causes gastroenteritis, although it tends to be associated with more persistent diarrhea. Other protozoa include Cryptosporidium species and Entamoeba histolytica. However, less developed countries have a higher rate of parasites and Escherichia coli infection which are both relatively uncommon in the industrialized countries. ${ }^{21}$ This indicates that improvement in sanitation will not decrease the disease prevalence of viral infection but can help in prevention of parasites and bacterial infections.

\section{Rotavirus as a prototypic virus for gastroenteritis}

Rotavirus is a prototypical virus because it is the most common virus that causes acute gastroenteritis in children which results in hospitalization and treatment with intravenous fluid. According to the data from the United States, approximately 410,000 physician visits are due to the rotavirus infection, the cause of 205,000 to 272,000 emergency department visits, which results in 55,000 to 70,000 hospitalizations. ${ }^{23}$ In the United States, 1 in $67-85$ children will be hospitalized because of rotavirus infection by the age of 5 years. ${ }^{24}$ On the other hand, Hong Kong has a very high rate of hospitalization. By the age of 5 years, the cumulative risk is 1 in 24, a figure that is 3 times higher than the that of the United States. ${ }^{9}$ For each admission in the United States, the hospital costs range from $\$ 2999$ to $\$ 3400$ with the family costs being $\$ 359$ which includes the caregivers loss of work. ${ }^{24-26}$ In Hong Kong, admission costs are less expensive although they are not unsubstantial at $\$ 1868$ (US) for each admission and $\$ 120$ for family expenses. ${ }^{9}$ Adding in the prevalence of the disease, gastroenteritis causes a significant economic burden to the health care system. As to the severity of the disease, a study that included 234 hospitalized children infected with rotavirus, $63 \%$ of them had diarrhea, vomiting and fever, $21 \%$ had diarrhea and vomiting, 7\% had diarrhea and fever, 4\% had vomiting and fever, $3 \%$ had fever alone, $2 \%$ had vomiting alone and $0.4 \%$ had diarrhea alone. ${ }^{27}$ In general, $90 \%$ of the hospitalized patients had vomiting. Vomiting is one of the most important symptoms for considering failure of oral rehydration therapy and requiring intravenous therapy. ${ }^{28,29}$

\section{Oral rehydration therapy versus intravenous therapy}

The American Academy of Pediatrics (AAP), Centers for Disease Control and Prevention (CDC), European Society for Pediatric Gastroenterology and Nutrition, and the World Health Organization (WHO) all strongly support the use of oral rehydration therapy as the first-line therapy for the treatment of acute gastroenteritis, except in cases of severe dehydration. ${ }^{2,30-32}$ The effectiveness of oral rehydration therapy in treating acute gastroenteritis, with mild to moderated dehydration, has been demonstrated by many randomized controlled trials. In a Cochrane meta-analysis of 17 trials from 1982 to 2005, in which 9 trials were from the developed countries, 7 trials from developing countries and 1 trial involving developed and less developed countries. ${ }^{33}$ Included in this analysis were more than 1800 participants. The data showed that there were no important clinical differences between oral hydration therapy and intravenous therapy for rehydration secondary to acute gastroenteritis in children; and that children treated with oral rehydration therapy spent less time in hospitals. Moreover, patients receiving intravenous therapy had a $2.5 \%$ risk of phlebitis that did not occur in the oral rehydration group. Importantly, this result is unlikely to change with further trials because there 
is already adequate power to support the observed results and further research comparing oral rehydration therapy and intravenous therapy is not warranted and may be unethical. The effectiveness of oral rehydration therapy is not isolated to just clinical trials it can also be reflected in the decreased mortality rate. In 1970's the diarrheal illness related deaths were 4.6 million/year worldwide. ${ }^{34}$ After the promotion of oral rehydration therapy by World Health Organization (WHO) at the end of 1970's, the diarrheal illness related death rate dropped to 3.3 million/year in 1980's, with a further drop to 2.5 million/year in 1990 's. ${ }^{35}$

The oral rehydration solution is regarded as one of the most important medical advances of the 20th century. Although there is much evidence to support the usage of oral rehydration with numerous published guidelines and many professional organizations recommending its use, oral rehydration solution is still described as an underused simple therapy. ${ }^{36}$ Intravenous therapy is still often chosen rather than oral rehydration therapy. Data from Europe, Australia and Canada show that $80 \%$ to $94 \%$ of hospitalized children do not have any signs of dehydration and yet they still receive intravenous therapy. ${ }^{37-39}$ Data from Hong Kong, that assessed more than 7000 episodes of admission due to gastroenteritis in children under 5 years of age, also showed that only $1.3 \%$ to $8.4 \%$ had signs of dehydration and yet up to $48 \%$ of the patients received intravenous therapy. ${ }^{40}$ The rate of intravenous therapy was even higher in the rotavirus group. According to a recent survey, $45 \%$ of physicians still preferred intravenous fluid therapy rather than oral rehydration therapy in treating moderate dehydration in acute gastroenteritis. ${ }^{41}$ However, judging the effectiveness of oral rehydration therapy and the overuse of the intravenous therapy, any treatments in acute gastroenteritis should improve the success or compliance of oral rehydration therapy as the top priority. Safety and cost are also important issues. Successful oral rehydration therapy always means that the children can be managed in the community. It is more pleasant for the children and more comfortable for the caregivers. Oral rehydration therapy also helps to save money by reducing the hospitalization costs.

\section{Reasons of underused oral rehydration therapy}

The reasons for the underuse of oral rehydration therapy are not fully understood. In 2002 Ozuah and colleagues published a national random survey of emergency physicians selected from the mailing list of the AAP that addressed this issue. ${ }^{29}$ A total of 176 physicians responded (73\% response rate).
Their responses can be divided into four categories: the physician factors; patient factors; parental concern; and environment or social factors. Regarding the physician factors; in contrast to the group of physicians unfamiliar with the AAP guidelines, the familiar group was more likely to use oral rehydration therapy in scenarios of mild dehydration ( $81 \%$ versus $66 \%)$ and moderate dehydration $(25 \%$ versus $10 \%$ ). Parental concern about dehydration (disregarding the actual hydration status of the patients) would make $31 \%$ of the emergency department physicians choose intravenous therapy over oral rehydration therapy. A crowded or emergency department with long waiting times would cause $22 \%$ of the physicians to choose intravenous therapy. Regarding the severity of dehydration, $49.4 \%$ of emergency department physicians would offer intravenous therapy even in moderate dehydration. In terms of symptoms, only $8 \%$ of the emergency department physicians would consider intravenous therapy when diarrhea was a major symptom. On the other hand, patients refusing to drink was the most likely reason for choosing intravenous therapy (up to 96\%). Vomiting was the second most important reason given for intravenous therapy, with up to $85 \%$ of the physicians being more likely to use intravenous therapy when vomiting was the predominant symptom. In another study, up to $36 \%$ of the surveyed physicians believed that vomiting was a contraindication for oral rehydration therapy. ${ }^{28}$

Approximately $70 \%$ of all children with gastroenteritis also present with vomiting. ${ }^{37}$ According to our own unpublished data ( of more than 7000 episodes of hospitalization in Hong Kong due to acute gastroenteritis in children younger than 5 years of age) $62 \%$ of gastroenteritis patients presented with vomiting. Up to $82 \%$ of rotavirus infected children presented with vomiting, a figure that was very similar to the study by Staat and colleagues in $2002 .{ }^{27}$ In terms of the episodes and duration of vomiting in gastroenteritis patients, the mean number of vomiting episodes was 4.91/24 hours and for a duration of 1.84 days. In summary this may partly explain why the oral rehydration solution is an underused simple solution.

\section{The pathophysiology of vomiting and the mechanisms of antiemetic medications}

Vomiting is usually defined as a violent expulsion of the stomach contents through the mouth and being a very unpleasant symptom. It can also be associated with nausea and retching. The mechanism of vomiting has been well characterized, first by Borison and Wang in $1953 .{ }^{42}$ 
The vomiting center controls and integrates the act of vomiting. It is located in the lateral reticular formation of the medulla oblongata, which is close to other centers that regulate respiration, vasomotor, and other autonomic functions. These centers too may also play an additional role in vomiting. Emetic stimuli can be transmitted directly to the vomiting center or through the chemoreceptor trigger zone. The chemoreceptor trigger zone, located in the area postrema of the fourth ventricle and outside the blood-brain barrier, is exposed to both cerebrospinal fluid and blood. ${ }^{43}$ This would allow the chemoreceptor trigger zone to pick up the chemical signals from both cerebrospinal fluid and blood stream (such as bacterial toxins or form metabolic abnormalities that occur with uremia) and act as an afferent limb to the vomiting center; however, it cannot independently mediate the act of vomiting without the interaction of vomiting center. On the other hand, the vomiting center does not only receive information from the chemoreceptor trigger zone, it can also receive information and stimulation from the cerebral cortex and limbic system, the vestibular system, and the vagal and splanchnic afferents. ${ }^{42,44,45}$ Psychological stress such as fear can act on cerebral cortex and limbic system to induce vomiting via the vomiting center. Vomiting due to motion sickness develops consequent to stimulation of the vestibular system, with impulses that travel from the labyrinth of the inner ear to the vomiting center.

However, the exact mechanism of vomiting in gastroenteritis is not known; although it is thought to be due to the peripheral stimuli arising from the gastrointestinal tract primarily via the vagus nerve or via serotonin stimulation of the 5-hydroxytryptamine 3 (5HT3) receptors in the gut. ${ }^{46-49}$ In acute gastroenteritis, intestinal irritation can damage the gastrointestinal mucosa and result in the release of serotonin from the enterochromaffin cells. This serotonin acts on the 5HT3 receptors of the vagal afferent nerves in the gastrointestinal tract, ${ }^{49}$ which are then transmitted to the vomiting center directly or via the chemoreceptor trigger zone. The vomiting center then sends efferent impulses to the diaphragm, abdominal muscles, and visceral nerves of the stomach and esophagus to produce vomiting. ${ }^{50,51}$ These events typically include: an increase in salivation; a decrease in gastric tone that results in the sensation of nausea; nonperistaltic contractions in the small intestine; regurgitation of the intestinal contents into the stomach; contractions of the respiratory and abdominal muscles; and the descent of the diaphragm against a closed glottis such that the gastric contents are forced up into the esophagus and out through the mouth.
Antiemetic therapy aims at: depressing the vomiting center; depressing the chemoreceptor center; inhibiting the impulses from chemoreceptor zone to vomiting center; and/or inhibiting impulses from peripheral receptors to the vomiting center. All the areas involved in the pathogenesis of vomiting are rich in serotoninergic, dopaminergic, histaminic, and muscarinic receptors. ${ }^{45}$ Dopamine antagonists suppress proemetic stimuli by blocking $\mathrm{D}_{2}$ receptors in the chemoreceptor trigger zone. 5-HT3 antagonists have been more recently developed to block the nausea and vomiting reflexes mediated by stimulation of 5-HT3 receptors in both the small intestine and the chemoreceptor center. Antihistamines, although widely used for migraine, are generally recommended for motion sickness as they act at the level of the vestibular apparatus. ${ }^{43,52}$ Anti-cholinergic agents such as atropine and hyoscine are relatively ineffective in the treatment or prevention of vomiting due to causes other than motion sickness. ${ }^{52-54}$ The mechanism of action is not clearly understood in some antiemetic medications such as dexamethasone and trimethobenzamide.

\section{The use of antiemetics in acute gastroenteritis}

In 1996, the AAP made the following statement: "The committee did not evaluate the use of antiemetic drugs. Consensus opinion is that antiemetic drugs are not needed. Physicians who feel that antiemetic therapy is indicated in a given situation should be aware of potential adverse effects" ${ }^{31}$ In 2003, the Centers for Disease Control and Prevention (CDC) released an updated statement regarding the usage of antiemetics. It also concluded that antiemetics are usually unnecessary. Reliance on pharmacologic agents shifts the therapeutic focus away from appropriate fluid, electrolyte, and nutritional therapy, that can result in adverse events, and can add unnecessarily to the economic burden of the illness. ${ }^{2}$ Notwithstanding the lack of an official recommendation for their use, antiemetics are still commonly prescribed among different specialties and countries in the management of acute gastroenteritis.

Antiemetics are often used because vomiting is an unpleasant and a distressing symptom which can increase the likelihood of dehydration, electrolyte imbalance, pulmonary aspiration, and most importantly the need for intravenous hydration or hospitalization. ${ }^{55-58}$ The reasons why antiemetics are not commonly recommended for gastroenteritis related vomiting are because vomiting is self-limiting, vomiting is a normal physiological reaction for ridding the body of toxic substances, and antiemetics can have adverse side 
effects. ${ }^{10,38,59}$ In addition, the newer antiemetics are also costly.

O'Loughlin and colleagues prospectively surveyed all children with acute vomiting or diarrhea who were admitted to a pediatric inpatient facility in Newcastle, NSW, Australia, during a 12-month period. The authors found that antiemetic medication was administered to 21 (9\%) of 231 children prior to admission. ${ }^{59}$ Elliott and colleagues found that antiemetic medications were prescribed for the treatment of acute gastroenteritis in $9(5.5 \%)$ of 164 children prior to admission to the Royal Alexandra Hospital for Children in Sydney, NSW, Australia, during a 6-month period. ${ }^{38}$ Nelson and colleagues interviewed the caregivers of 105 pediatric in-patients with gastroenteritis in Hong Kong where up to $73 \%$ had seen one or more primary care practitioners prior to admission to hospital, and $29 \%$ of cases were prescribed antiemetics. $^{60}$

In 2002, Kwon and colleagues conducted a national survey to address this problem in the United States among emergency physicians, general pediatricians and pediatric emergency physicians. ${ }^{61}$ In this study, $79.2 \%$ of emergency physicians would prescribe antiemetics as compared to $52.2 \%$ of general pediatricians and $55.2 \%$ of pediatric emergency physicians. The use of antiemetics by emergency physicians was greater than the other two specialties $(P<0.001)$. The most commonly nonexclusive reason for prescribing antiemetic use was to prevent the worsening dehydration and the need for subsequent intravenous fluids or admission (72.0\%). This was followed by patient comfort (59.0\%), assurance/documentation of oral liquid trial in emergency department/clinic/office before discharge (35.5\%), and parental concerns/pressures (29.4\%). Albano and colleagues conducted a similar survey to look at the practice of Italian hospital pediatricians and family physicians. ${ }^{62}$ Approximately $71 \%$ of hospital pediatricians would use antiemetic medications as compared to $96 \%$ of the family physicians. When comparing the reasons for prescription by family physicians versus hospital pediatricians, the latter were more likely to prescribe antiemetics in order to increase the success rate of oral rehydration therapy (48\%), whereas family physicians prescribed them to increase patient comfort or to reduce concerns of parents $(46 \%)$.

Pfeil and colleagues investigated the prescription pattern of antiemetic medications in 0- to 9-year-old children with infectious gastroenteritis in several industrialized countries during 2005. ${ }^{63}$ The authors retrospectively retrieved data from four national and international databases which showed that between $2 \%$ and $23 \%$ of children with gastroenteritis received prescriptions for antiemetic medications (United States, 23\%; Germany, 17\%; France, 17\%; Spain, 15\%; Italy, 11\%; Canada, 3\%; United Kingdom, 2\%).

In summary, antiemetic drugs are frequently used in children with gastroenteritis by physicians in various specialties and in various countries in spite of the lack of an official recommendation for their use.

\section{Antiemetic medications Serotonin 5HT3 receptor antagonists Ondansetron}

Ondansetron is a carbazole derivative that has been available since 1991. It is one of the best known potent serotonin 5-HT3 receptor-antagonists that blocks receptors at the vagus and sympathetic nerves together with the chemoreceptor trigger zones. ${ }^{64}$ It has no antidopaminergic properties. The efficacy of ondansetron for chemotherapy-induced or postoperative vomiting in the pediatric population is well documented. ${ }^{65,66}$ It also has promising effects in patients with vomiting due to migraines, procedural sedation with ketamine and acetaminophen poisoning. ${ }^{67-69}$

These positive results initiated investigations for their use in gastroenteritis related vomiting. However, only a few randomized controlled trials regarding its use in pediatric gastroenteritis have been published. In 2008, DeCamp and colleagues published a meta-analysis in order to address this question..$^{70}$ The investigators reviewed prospective controlled trials only and looked at the emesis cessation, use of intravenous fluid for rehydration, hospital admission, return to care, and medication adverse effects as the principal outcomes. There were 11 articles that met the inclusion criteria. Ondansetron has the greatest number of studies that met the criteria $(n=6$, participants $=745) \cdot{ }^{55,71-75}$ All of the studies were conducted in the emergency department setting, except the study by Cubeddu and colleagues that was performed in an in-patient setting. ${ }^{55}$ The majority of studies included only children but the study by Reeves and colleagues also included patients up to 22 years of age. ${ }^{72}$ Among the six studies, the two studies published by Reeves et al and Freedman et al required dehydration as an inclusion criterion. ${ }^{72,74}$ The study published by Roslund and colleagues and Stork and colleagues, required both dehydration and failure of oral rehydration as the inclusion criteria. ${ }^{71,75}$ However, all the participants in the study by Stork and colleagues received intravenous therapy. ${ }^{71}$ In all except one study, only one dose of ondansetron was administered during the study period. The study by Ramsook and colleagues provided families with 
additional doses for home use. ${ }^{73}$ Routes of administration and dosing varied across studies. There were 3 studies using intravenous ondansetron. Among these 3 studies, both Stork et al and Reeves et al used a dose of $0.15 \mathrm{mg} / \mathrm{kg},{ }^{71,72}$ whereas Cubeddu and colleagues used a dose of $0.3 \mathrm{mg} / \mathrm{kg} .{ }^{55} \mathrm{Among}$ the 3 studies of oral ondansetron, Freedman et al and Roslund et al used similar weight-based dosing ranging from 2 to $8 \mathrm{mg},{ }^{74,75}$ and Ramsook and colleagues used age-based dosing ranging from 1.6 to $4.0 \mathrm{mg} \cdot{ }^{73}$ The follow-up period ranged from 24 hours to 2 weeks.

Five studies (659 participants) reported whether patients continued to have emesis in the emergency department after administration of the study drug. Using data from these five studies, the relative risk (RR) for vomiting after the ondansetron compared to placebo was 0.45 ( $95 \%$ confidence interval $[\mathrm{CI}]$ : $0.33-0.62$; number needed to treat $[\mathrm{NNT}]=5) .{ }^{70}$ Four studies (489 participants) reported the use of intravenous fluid. However, the indications for intravenous fluid varied from study to study and included persistent emesis, refusal to drink, and persistent or worsening states of dehydration. It also showed a statistically significant reduction in the RR of intravenous fluid use for patients who received ondansetron versus placebo (RR, 0.41; 95\% CI: $0.28-0.62$; NNT = 5). ${ }^{70}$ Five trials (662 participants) included hospital admission as an outcome. Patients who received ondansetron had a statistically significant decrease in risk of immediate hospital admission (RR, 0.52; 95\% CI: $0.27-0.95$; NNT $=14$ ). ${ }^{70}$ Five trials (612 participants) assessed whether patients returned to outpatient care during the study period. Ondansetron use did not significantly affect return to care (RR, 1.34; 95\% CI: $0.77-2.35) .{ }^{70}$ With regard to the RR of admission during the whole study period, there was also no significant difference between the treatment group and the controlled group (RR, 0.69; 95\% CI: 0.43-1.11). ${ }^{70}$

Five studies documented the severity of diarrhea after ondansetron administration. Overall, three studies have documented an increased severity of diarrhea after the ondansetron. Freedman and colleagues reported an increase in diarrhea during the emergency department stay although they did not evaluate the incidence of diarrhea during followup. ${ }^{74}$ Ramsook and colleagues did not detect any difference in the severity of diarrhea during the emergency department stay but reported an increase in severity in 48 hours after discharge from the emergency department. ${ }^{73}$ Cubeddu and colleagues also reported more diarrhea episodes in the 24 hours after the ondansetron administration. ${ }^{55}$ On the other hand, the studies by Roslund et al and Reeves et al detected no differences in diarrheal episodes 5 to 7 days after discharge from the emergency department. ${ }^{72,75}$ In summary, although an increase in diarrhea was noted in the ondansetron group up to 48 hours after administration, no difference in frequency was detected afterwards. No other adverse event was systemically evaluated and no other adverse effects were common across different studies.

The most recent Cochrane meta-analysis was performed by Alhashimi and colleagues who used very strict inclusion criteria and excluded the studies by Reeves et al and Stork et al. ${ }^{76}$ The authors came to a similar conclusion, that ondansetron may reduce the amount of acute vomiting as well as reducing the number of children who required intravenous rehydration, and admission for acute gastroenteritis. However, participants in the ondansetron group did have more diarrhea than in the placebo group.

There was one randomized, double blind, placebo controlled trial that was published in 2009 , however, it was not included in the previous meta-analysis. ${ }^{77}$ This study was also performed in emergency department. A total of 109 children aged from 5 months to 8 years who had nonbilious, nonbloody vomiting at least 4 times in the last six hours, who could not tolerate oral feeding, who had at least 4 episodes of diarrhea in the previous 24 hours, and who had mild to moderate dehydration were recruited. Oral ondansetron $(0.2 \mathrm{mg} / \mathrm{kg} / \mathrm{dose})$ was administered at 8 hourly intervals with a total of 3 doses. The frequency of vomiting was significantly lower among the children who received ondansetron than among those who received placebo $(0.36$ versus $1.33, P<0.001$ and 0.2 versus $1.66, P<0.001$ at four hours and twenty-four hours respectively). Weight gain in the ondansetron group was significantly higher than that of the placebo group at eight hours after intervention. At the end of the study, 5.4\% (3/55) in the ondansetron group and $18.6 \%(10 / 54)$ in the placebo group failed oral rehydration therapy $(\mathrm{RR}=0.29 ; 95 \% \mathrm{CI}$ : $0.086-1.01 ; P=0.04)$. The authors found that the absolute risk of reduction and the number needed to treat were $13.2 \%$ and $8 \%$, in terms of hospitalization and/or intravenous rehydration treatment. In terms of side effects, the children who received ondansetron had more episodes of diarrhea while undergoing oral rehydration than those who received placebo at 24 hours $(P=0.04)$. All of the randomized controlled trials (RCT) evaluating the efficacy of ondansetron in acute gastroenteritis are summarized in Table 1.

The safety profile of ondansetron is favorable, as in the treatment of gastroenteritis, diarrhea is the most common and only reported side effect according to the 7 randomized controlled trials involving 854 participants. However, diarrhea associated with this treatment is usually mild and 


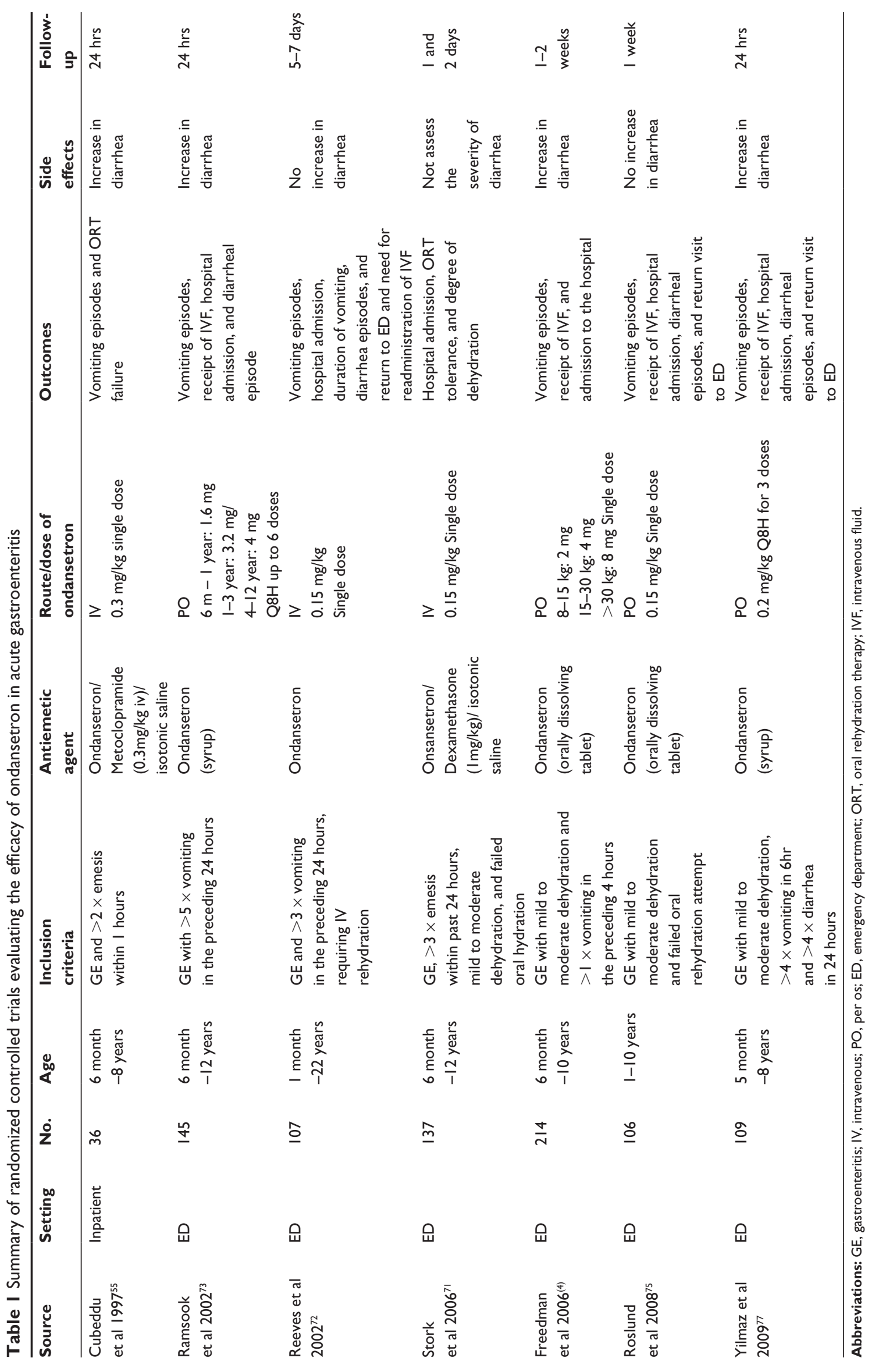


self-limiting. Furthermore, the study by Bryson, evaluating the use of ondansetron in the treatment of postoperative emesis in 1900 patients, found the incidence of adverse events was similar to that of placebo. ${ }^{78}$ It did not cause extraparamidal reactions or sedation. ${ }^{56}$ However, in other large clinical trials, including some pediatric patients, documented headache as the most common adverse effect, followed by fatigue and constipation. ${ }^{79}$

Ondansetron has a good tolerability. It is completely and rapidly absorbed from the gastrointestinal tract, and then metabolized by the cytochrome P450 enzyme system with subsequent glucuronide or sulfate conjugation in the liver. ${ }^{80-82}$ It also has a low potential for drug interactions. Peak plasma concentration occurs approximately 2 hours post oral and the bioavailability is approximately $60 \%{ }^{80}$ Peak plasma concentration occurs 40 minutes post intramuscular administration, and 10 minutes post intravenous administration. It has a half-life of 2 to 6 hours. ${ }^{81}$ Its antiemetic duration of action is variable from 2 to 8 hours with standard dosing. The recommended intravenous dose of ondansetron is 0.1 to $0.15 \mathrm{mg} / \mathrm{kg}$ body weight, up to a maximum of $4 \mathrm{mg} .{ }^{81}$ The recommended oral dose is $2 \mathrm{mg}$ for children weighing 8 to $15 \mathrm{~kg}, 4 \mathrm{mg}$ for children weighing 15 to $30 \mathrm{~kg}$ and $8 \mathrm{mg}$ for children weighting $>30 \mathrm{~kg}$ up to a maximum of 3 times/day. However, a single dose of oral ondansetron is usually sufficient for the treatment of gastroenteritis related vomiting.

The main drawback of ondansetron has been the cost; however, a generic form of ondansetron has recently been available and so cost is no longer a barrier to its use. In addition, the use of the medication can minimize the need for hospitalization (NNT $=14$ ) and intravenous therapy $(\mathrm{NNT}=5) \cdot{ }^{70}$ Even so there has been no formal study in terms of the cost saving, although judging from the very high costs associated with hospitalization, the use of this medication may reduce the overall health care costs of treating patients with gastroenteritis.

\section{Other $5 \mathrm{HT} 3$ receptor antagonists}

These include granisetron, tropisetron, dolasetron and ramosetron. These medications have been evaluated in the management of post-operative and chemotherapy related nausea and vomiting. One trial comparing granisetron and ondansetron and another comparing granisetron, tropisetron and ondansetron in children undergoing chemotherapy found no significant differences in efficacy outcomes. ${ }^{83,84}$ Three trials have compared dolasetron and ondansetron in children undergoing surgical procedures and these also showed no significant difference in terms of efficacy. ${ }^{85-87}$ There has been no controlled trial directly comparing ramosetron and ondansetron. Moreover, none of these new 5HT3 receptor antagonists have evaluated in the treatment of gastroenteritis related vomiting. Although one advantage of these medications is that their longer half-life, the main disadvantage is they are usually more expensive.

\section{Other antiemetic medications}

\section{Antihistamine}

\section{Dimenhydrinate}

Dimenhydrinate is a first generation $\mathrm{H} 1$ receptor antagonist. It not only blocks the $\mathrm{H} 1$ receptors in the nucleus tractus solitarius, it also blocks the muscarinic-cholinergic receptors in both the vestibular apparatus and the vomiting center. ${ }^{43,82}$ Dimenhydrinate is very convenient to use because it can be given via oral, rectal, intramuscular or intravenous routes. ${ }^{88}$ The recommended dose is $1.25 \mathrm{mg} / \mathrm{kg}$ body weight, with a maximum of $50 \mathrm{mg} .{ }^{43,82}$ It has also been used for the treatment and prevention of motion sickness, radiation sickness, disturbances of labyrinthine function, and post operative nausea and vomiting. ${ }^{89-92}$ The cost of dimenhydrinate is a lot less expensive when compared to ondansetron. The main concern for the use of dimenhydrinate in the treatment of acute gastroenteritis related vomiting is its sedative effect. It can jeopardize the oral intake of rehydration fluids and further aggravate dehydration. There have been no efficacy studies for dimenhydrinate in gastroenteritis until recently. In 2009, Uhlig and colleagues published a prospective, randomized, placebo controlled, multicenter trial investigating dimenhydrinate in children with infectious gastroenteritis. ${ }^{93}$ The investigators randomly assigned 243 children (aged between 6 months and 6 years) with presumed gastroenteritis related vomiting to treatment with rectal dimenhydrinate or placebo. The dose of dimenhydrinate depended on body weight (40 mg $<15 \mathrm{~kg}$ bodyweight; $80 \mathrm{mg}$ for 15 to $25 \mathrm{~kg}$ bodyweight and $120 \mathrm{mg}$ for bodyweights $>25 \mathrm{~kg}$ ). Additional doses could only be given in case of visible excretion of the suppository immediately after administration or in case of persistent vomiting. Children with none or mild dehydration were included. All children received oral rehydration therapy. A short-term follow-up visit in the study center was scheduled at 18 to 24 hours after treatment. The investigators called the families for a telephone interview 7 to 14 days after enrollment. There was no change of bodyweight between children who received dimenhydrinate or placebo. The mean number of vomiting episodes between treatment and the follow-up visit was 0.64 in the dimenhydrinate group and 
1.36 in the placebo group. In total, $69.6 \%$ of the children in the dimenhydrinate group versus $47.4 \%$ in the placebo group were free of vomiting between treatment and the follow-up visit. The numbers needed to treat were 2 (95\% CI: $1-4)$ to avoid 1 episode of vomiting and 5 (95\% CI: 3-12) for complete cessation of vomiting. Hospital admission rate, fluid intake, general well-being of the children, parental satisfaction and potential adverse effects, including the number of diarrheal episodes, were similar for both groups. Sedation occurred in $21.6 \%$ children who received dimenhydrinate and $18.6 \%$ children who received placebo. The study showed that dimenhydrinate reduced the frequency of vomiting in children with mild dehydration; however, the overall benefit was low, because it did not improve oral rehydration or clinical outcome.

\section{Promethazine}

Promethazine is derived from phenothiazines with pronounced antihistamine activity. ${ }^{43}$ It also has anti-cholinergic and antidopaminergic activities ${ }^{88}$ Promethazine has also been used in the management of post-operative nausea and vomiting and motion sickness. ${ }^{57,88}$ The medication is not expensive and can also be given orally, rectally, intramuscularly or intravenously with a doses of $0.25 \mathrm{mg}$ to $1 \mathrm{mg} / \mathrm{kg}$ bodyweight (up to a maximum of $25 \mathrm{mg}$ ) every 4 to 6 hours as required..$^{43}$ It is well absorbed orally with clinical effects beginning 20 minutes after administration. There has been only one study published, that being by Tibbs in 1968 involving 60 children that use promethazine and pyrilamine-pentobarbital for the treatment of children with vomiting from gastroenteritis. ${ }^{94}$ However, this study did not include a placebo group and included children with a variety of illnesses other than gastroenteritis. However, it showed that promethazine was less effective than pyrilamine-pentobarbital for the relief of vomiting.

Since its approval in 1951, serious and often lifethreatening adverse events; including respiratory depression; over sedation; agitation; hallucinations; seizures; and dystonic reactions have been reported with promethazine use in children. ${ }^{95,96}$ As of 2005, there were 38 cases of respiratory depression, apnea, or cardiac arrest reported to the Food and Drug Administration (FDA). ${ }^{97}$ Twenty two of them were in children aged 1.5 months to 2 years of age, 7 of which died. Nine of these 22 patients received $1 \mathrm{mg}$ or less of promethazine per kilogram of bodyweight, plus another drug with respiratory depressant effects. A wide range of weight-based doses ( 0.45 to $6.4 \mathrm{mg}$ per $\mathrm{kg}$ ) were associated with respiratory depression. Serious outcomes, including death, disability, life-threatening events, and hospitalization, occurred with all routes of administration (oral, rectal, and parenteral). Because of this, in late 2004, a "boxed warning" was added to the labeling for promethazine hydrochloride (Phenergan), including a contraindication for use in children less than two years of age and a strengthened warning with regard to the use in children two years of age or older. It should also not be prescribed to children who are already on other drugs with respiratory depressant effects as it may further aggravate the effect on respiratory depression.

\section{Dopamine receptor antagonists Metoclopramide}

Metoclopramide is a chlorinated procainamide derivative that has been marketed since the 1960s. It acts primarily as a $\mathrm{D}_{2}$ receptor antagonist and also has parasympathomimetic activity with weak 5-HT3 receptor antagonist activity ${ }^{88}$ It has both central and peripheral actions, and alleviates nausea and vomiting by decreasing afferent impulses to the chemoreceptor trigger zone, lowering gastric sphincter tone, stimulating gastric motility and accelerating gastric emptying and small intestine transit time. It has been used for the prevention of chemotherapy related vomiting, post-operative nausea and vomiting, and pregnancy associated nausea and vomiting. ${ }^{98}$ Two studies evaluated metoclopramide as a treatment for vomiting associated with gastroenteritis in 96 hospitalized children. ${ }^{55,99}$ The first double blind, randomized, controlled study, in 1979, was published by Van Eygen and colleagues. ${ }^{99}$ The authors recruited 60 children aged between 2 to 6 years in an in-patient setting. The children were randomized to receive a suppository that contained placebo $(\mathrm{n}=20)$, domperidone $30 \mathrm{mg}(\mathrm{n}=20)$ or metoclopramide $10 \mathrm{mg}(\mathrm{n}=20)$ at study entry repeated up to 3 times throughout the 24 hour period as clinically warranted. This study found that metoclopramide was more effective than placebo in reducing symptoms of nausea and vomiting. No adverse events were reported. However, a second study by Cubeddu and colleagues found that although metoclopramide reduced the number of vomiting episodes the results did not reach any statistical significance. ${ }^{55}$ Significantly more episodes of diarrhea were reported during the first 24 hours in the metoclopramide group than the placebo group.

Metoclopramide can be given intravenously, intramuscularly or orally at a dose of $0.1 \mathrm{mg} / \mathrm{kg}$ (up to a maximum of $10 \mathrm{mg}$ ), with the onset of action 1 to 3 minutes, 10 to 15 minutes, and 30 to 60 minutes, respectively. ${ }^{61}$ The half-life is 5 to 6 hours with a duration of action of 1 to 2 hours. ${ }^{61}$ Reported adverse effects in patients who received metoclopramide included: drowsiness, cough, and tremor. Extrapyramidal reactions such as dystonia, 
akathisia and oculogyric crisis are more common in children and reported in up to $25 \%$ of children. ${ }^{100,101}$ Extrapyramidal reactions occur regardless of the doses, (whether single or multiple doses) or routes of administration. Other severe reactions such as: seizures; neuroleptic malignant syndrome; methemoglobinemia; sulfhemoglobinemia; and gynecomastia have also been reported. ${ }^{102-104}$

\section{Droperidol}

In June 1968 McNeil laboratories submitted a new drug application for droperidol to the FDA. The drug was approved, on June 11 1970, for use preoperatively, during induction and maintenance for sedation or tranquilization, for anti-anxiety activity, and for the reduction of the incidence of nausea and vomiting. Droperidol is classified as a short acting butyrophenone and a potent $\mathrm{D}_{2}$ receptor antagonist that also has weak anti-cholinergic and antihistamine activity. ${ }^{43}$ It is pharmacologically related to phenothiazines and thought to act both centrally and peripherally. Droperidol has been well studied as a postoperative antiemetic agent, but there are no studies on its efficacy in gastroenteritis related vomiting. ${ }^{105-107}$ It has a good anti-nausea effect although a lesser antiemetic effect. ${ }^{108}$ The recommended dose of droperidol for vomiting is 0.05 to $0.06 \mathrm{mg} / \mathrm{kg}$ bodyweight/dose every 4 to 6 hours intramuscularly or intravenously and the onset of action is within 3 to 10 minutes with a half-life of 2 hours. Droperidol is not recommended in children younger than 2 years because its safety and efficacy have not yet been established. The side effects of droperidol are mainly prolonged CNS depression and extrapyramidal symptoms. Sedative effects can last up to 12 hours. ${ }^{109}$ However, in 2001, the FDA posted a black box warning that droperidol could cause QT prolongation and torsades de pointes. The warning was based on 273 cases reported over a 4 -year period. ${ }^{110}$ Before administration of droperidol, a 12-lead electrocardiogram should be performed. Furthermore, the patient must have electrocardiographic monitoring for 2 to 3 hours after droperidol administration. Manufacturers now only recommend droperidol in patients who fail to show a response to other treatments. Janssen Pharmaceuticals has also stopped marketing droperidol outside of the United States since 2001. The fallout from the black box warning has the been near cessation of droperidol use in the United States. ${ }^{11,112}$

\section{Domperidone}

Domperidone was first synthesized in 1974 and acts as a $\mathrm{D}_{2}$ receptor antagonist. It acts on the chemoreceptor trigger zone and it can also accelerate gastric emptying time. Domperidone has been used for prevention and treatment of post-operative nausea and vomiting. There have been two studies that included 109 hospitalized children, aged between 8 months to 10 years old, which examined its antiemetic effect in children with gastroenteritis. ${ }^{99,113}$ Unfortunately, the enrollment in both studies was not limited to patients with gastroenteritis, although both of them demonstrated that domperidone suppositories decreased the symptoms of nausea and vomiting when compared with placebo. Domperidone is now only available for oral or suppository administration because cardiac arrhythmias have been reported after high intravenous dose administration; therefore, the intravenous route of administration was discontinued. ${ }^{114-116}$ The recommended oral dose is 0.3 to $0.6 \mathrm{mg} / \mathrm{kg}$ bodyweight, with a maximum of $25 \mathrm{mg}$ three times a day. ${ }^{82}$ The recommended rectal dose is $10 \mathrm{mg}, 30 \mathrm{mg}$ and $60 \mathrm{mg}$ twice/day for children age $<2$ years, 2 to 6 years and $>6$ years, respectively. ${ }^{82 ; 99}$ After oral administration, peak plasma levels of domperidone occur after 30 minutes. Peak levels after the rectal administration of suppositories is usually achieved after 1 to 2 hours. Adverse effects of domperidone include ventricular arrhythmias and cardiac arrest. ${ }^{82}$ Unlike metoclopramide, which also has both central and peripheral effects, domperidone does not cause any significant extrapyramidal adverse effects because of its poor penetration into the central nervous system. Domperidone is currently available in many countries and there is worldwide experience in the use of this agent. In the past 3 years, domperidone has been available in the United States through a compassionate clearance program.

\section{Prochlorperazine}

Prochlorperazine is a phenothiazine derivative that belongs to the piperazine class of drugs. It is a weak dopamine receptor blocker and depresses the chemoreceptor trigger zone. It was first introduced as an antipsychotic in the 1950s and subsequently found to be effective for controlling vomiting in 1956 and extended its usage in children in $1958 .{ }^{117}$ It is indicated for control of severe nausea and vomiting, but not recommended in patients less than 2 years or $9 \mathrm{~kg}$. Its efficacy in pediatric gastroenteritis has not been documented. Even in adults, only 3 prospective studies are known to exist. ${ }^{57,118,119}$ These 3 studies also included vomiting from other causes. The authors compared prochlorperazine to promethzine or trimethobenzamide. All these 3 studies showed that prochlorperazine is more effective than promethazine or trimethobenzamide for treating vomiting.

However, the medication is contraindicated in patients with hepatic or renal dysfunction. Akathisia and dystonia are the most common side effects in both adults and children in 
up to $44 \%$ of patients administered with this medication..$^{57,120,121}$ Children with acute illnesses such as gastroenteritis seem more susceptible to neuromuscular reactions, particularly dystonias, than adults. ${ }^{(122,123)}$ Other adverse effects include: drowsiness; depression; neuroleptic malignant syndrome; orthostatic hypotension; and prolongation of the QT interval. Tremor and tardive dyskinesia can occur after prolonged or chronic use, which are usually irreversible.

The recommended oral and rectal dose is 0.1 to $0.2 \mathrm{mg} / \mathrm{kg}$ bodyweight with a maximum dose of $5 \mathrm{mg}$ once daily to three times daily. ${ }^{43}$ The recommended intramuscular dose is $0.15 \mathrm{mg} / \mathrm{kg}$ bodyweight. ${ }^{43}$ Intravenous administration is not recommended in children. The onset of action following oral or rectal administration is 30 to 60 minutes with a half-life of 23 hours and duration of action of 3 to 4 hours.

\section{Unclassified antiemetics}

\section{Trimethobenzamide}

Trimethobenzamide is an unclassified antiemetic medication. Presumably, it acts on the chemoreceptor trigger zone. ${ }^{61}$ It is used for the treatment of post-operative nausea and vomiting. ${ }^{43}$ Regarding its clinical efficacy for treating vomiting in acute gastroenteritis in children, there are only 2 published randomized trials. The study published by Tibbs included 60 patients in a private pediatric clinic presenting with vomiting due to either gastroenteritis, pharyngitis or tonsillitis compared trimethobenzamide hydrochloride suppositories with pyrilamine-pentobarbital suppositories. ${ }^{94}$ Another study by Ginsburg and colleagues, randomized 49 children with acute gastritis who had experienced at least one episode of vomiting in the preceding 2 hours to receive a suppository that contained either trimethobenzamide $200 \mathrm{mg}$ $(n=24)$ or placebo $(n=25) \cdot{ }^{124}$ Both studies received low quality scores and showed that trimethobenzamide was no more effective than placebo, and was less effective than pyrilamine pentobarbital in treating vomiting due to gastroenteritis. ${ }^{70}$ Bardfeld conducted a controlled double-blind study of trimethobenzamide, prochlorperazine and placebo in patients older than 17 years of age. ${ }^{119}$ The author concluded that intramuscular prochlorperazine was more effective than trimethobenzamide for the treatment of nausea and vomiting. At the same time trimethobenzamide is no more effective than placebo for treating vomiting in gastroenteritis.

The recommended dose of trimethobenzamide is 4 to $5 \mathrm{mg} / \mathrm{kg}$ bodyweight with a maximum of $200 \mathrm{mg}$ up to 3 to 4 times/day administered orally or rectally. However, suppositories are contraindicated in premature or newborn infants and were removed from the market due to lack of efficacy. ${ }^{125}$ The injectable form is also contraindicated in pediatric patients. The onset of action, following an oral dose, is within 10 to 40 minutes with a half-life 3 to 6 hours and duration of action of 3 to 4 hours. Adverse reactions include extrapyramidal reactions, drowsiness, depression, headache and hypotension.

\section{Dexamethasone}

Dexamethasone is a potent synthetic member of the glucocorticoid class of steroid hormones. An action via its well known effects on eicosanoid metabolism, reduction in inflammation and edema is probably the most favored explanation for its antiemetic effects. ${ }^{126}$ It is seldom prescribed as an antiemetic in acute gastroenteritis but its effectiveness in chemotherapy induced emesis has been proved by randomized controlled trial. ${ }^{127}$ However, until recently there has been no randomized-controlled trial to assess it efficacy in treating vomiting in acute gastroenteritis. Stork and colleagues randomized patients with acute gastroenteritis-related vomiting to receive: dexamethasone (47patients) $1 \mathrm{mg} / \mathrm{kg}$ bodyweight intravenously, (with a maximum dose of up to $15 \mathrm{mg}$ ); ondansetron (46 patients) $0.15 \mathrm{mg} / \mathrm{kg}$ bodyweight; or placebo (44 patients) normal saline, $10 \mathrm{ml} \cdot{ }^{71}$ Hospital admission occurred in nine patients $(20.5 \%)$ receiving placebo (normal saline alone), two patients (4.4\%) receiving ondansetron, and seven patients (14.9\%) receiving dexamethasone. There were no significant differences in number of mean episodes of vomiting or repeat visits to health care providers at 24 and 72 hours in the ondansetron, dexamethasone, or normal saline groups. Dexamethasone was not very effective in treating acute gastroenteritis related vomiting, nor effective for reducing hospital admission in this study.

The numbers of randomized controlled trials for different antiemetics, doses and routes of administration, and special considerations are summarized in Table 2.

\section{The changing of pharmacoepidemiology of antiemetic medications}

In 2008, Pfeil and colleagues investigated the prescription pattern of antiemetic medications in 0 to 9 -year-old children with infectious gastroenteritis in several industrialized countries during $2005 .{ }^{63}$ The authors did not only look at the percentage of antiemetic prescriptions among patients with acute gastroenteritis, they also investigated the distribution of different antiemetics among the different countries. Antihistamines or dopaminergic receptor antagonists were prescribed preferentially in all countries. In Germany and 
Table 2 Summary of antiemetic drugs

\begin{tabular}{|c|c|c|c|}
\hline Drug & $\begin{array}{l}\text { No. of } \\
\text { RCT }\end{array}$ & Route/dose & Consideration \\
\hline Ondansetron & 7 RCTs & $\begin{array}{l}\text { PO: } 2 \mathrm{mg} \text { for BW } 8-15 \mathrm{~kg} \\
4 \mathrm{mg} \text { for BW } 15-30 \mathrm{~kg} \\
8 \mathrm{mg} \text { for } \mathrm{BW}>30 \mathrm{~kg} \\
\mathrm{IV}: 0.1-0.15 \mathrm{mg} / \mathrm{kg} \mathrm{BW}\end{array}$ & $\begin{array}{l}\text { Minimal adverse effects, with good evidence } \\
\text { for reduced admission and intravenous } \\
\text { therapy }\end{array}$ \\
\hline Dimenhydrinate & I RCT & $\mathrm{PO} / \mathrm{PR} / \mathrm{IM} / \mathrm{IV}: 1.25 \mathrm{mg} / \mathrm{kg}$ BW & Sedative effect \\
\hline Promethazine & I RCT & $\mathrm{PO} / \mathrm{PR} / \mathrm{IM} / \mathrm{IV}: 0.25-\mathrm{I} \mathrm{mg} / \mathrm{kg} \mathrm{BW}$ & FDA black box warning \\
\hline Metoclopramide & 2 RCTs & PO/IM/IV: $0.1 \mathrm{mg} / \mathrm{kg}$ BW & High frequency of extra-pyramidal reaction \\
\hline Droperidol & No RCT & IM/IV: $0.05-0.06 \mathrm{mg} / \mathrm{kg} \mathrm{BW}$ & FDA black box warning \\
\hline Domperidone & 2 RCTs & $\begin{array}{l}\text { PO: } 0.3-0.6 \mathrm{mg} / \mathrm{kg} \mathrm{BW} \\
\text { PR: }<2 \text { yr: } 10 \mathrm{mg}, 2-6 y \mathrm{r}: \\
30 \mathrm{mg},>6 \text { yr: } 60 \mathrm{mg}\end{array}$ & No IV as increase cardiac arrhythmias \\
\hline Prochlorperazine & No RCT & $\begin{array}{l}\text { PO: } 0.1-0.2 \mathrm{mg} / \mathrm{kg} \mathrm{BW} \\
\text { PR: } 0.1-0.2 \mathrm{mg} / \mathrm{kg} \mathrm{BW} \\
\text { IM: } 0.15 \mathrm{mg} / \mathrm{kg} \mathrm{BW}\end{array}$ & $\begin{array}{l}\text { Not recommended if }<2 y / I V \text { dosing not } \\
\text { recommended in pediatric patients }\end{array}$ \\
\hline Trimethobenzamide & 2 RCTs & $\begin{array}{l}\text { PO: } 4-5 \mathrm{mg} / \mathrm{kg} \text { BW } \\
\text { PR: } 4-5 \mathrm{mg} / \mathrm{kg} \mathrm{BW}\end{array}$ & $\begin{array}{l}\mathrm{PR} \text { form was removed from the } \\
\text { manufacture/IM/IV routes not } \\
\text { recommended in pediatric patients }\end{array}$ \\
\hline
\end{tabular}

Abbreviations: BW, body weight; PO, per os; PR, per rectum; IM, intramuscular; IV, intravenous; FDA, Food and Drug Administration; RCT, randomized controlled trial.

Canada, dimenhydrinate accounted most of the prescriptions. In the United States, promethazine was the most commonly prescribed antiemetic, even though the FDA had issued a black box warning. The dopamine receptor antagonist domperidone was preferred in Spain, France, Italy and United Kingdom. The prescription rate of ondansetron was $0 \%$ in Germany, Canada, Spain and Italy, $3 \%$ in United Status and $6 \%$ in United Kingdom. It seems that there is a strong variation among the different countries in the prescription pattern. The serotonin receptor antagonist ondansetron was prescribed in a small number of patients only. Cost was a barrier because as there was no generic form available at the time. Furthermore, the proof of therapeutic efficacy of ondansetron is relatively new. Physicians are just beginning to adopt the use of ondansetron as a strategy for avoiding intravenous therapy and hospitalization for children with gastroenteritis related vomiting. In 2009, the use of antiemetics in children between the ages of 1 and 10 years in emergency visits, reported to the National Ambulatory Medical Care Survey database, from 2002 to 2006 was published. ${ }^{128}$ The database included more than 3 million pediatric visits per year to emergency departments for acute gastroenteritis. The study showed the rate of prescribed ondansetron increased from $0.53 \%$ in 2002 to $6.42 \%$ in 2006 . A similar analysis of both emergency department and outpatient visits to academic medical centers and teaching hospitals from 2005 through to 2008, derived from the University Health System Consortium Clinical Database, showed a similar trend. ${ }^{128}$ Only $0.5 \%$ of those presenting to emergency departments and those seeking outpatient care for acute gastritis received ondansetron. However, the percentage had grown to $3.43 \%$ in emergency departments and $3.6 \%$ in outpatient care during 2008. After the availability of a generic formula of this drug it is anticipated that the use of ondansetron will most likely increase.

\section{The essential pillars of good treatment of acute gastroenteritis}

Oral rehydration therapy is still the key treatment for acute gastroenteritis. Many physicians still believe that antiemetic medications have no role in the management of acute gastroenteritis. However, after reviewing the existing literature, it is evident that ondansetron decreases the frequency of vomiting, improves the success and compliance of oral rehydration therapy and decreases the rate of intravenous therapy. It can also decrease the rate of hospitalization. Even though there is no formal economic study, judging from the high cost of hospitalization and the decreasing cost of the medication, it is likely that ondansetron can reduce the health care costs in patients presenting with acute gastroenteritis. When compared to placebo ondansetron does not increase revisited rate. It has a very good safety profile and does not have a sedative effect. The only drawback is the increased frequency of diarrhea after its usage; however this is usually transient and well tolerated. Although there is no study to evaluate parental satisfaction the success of oral rehydration therapy always means that the patients can be 
managed at home; which is more comfortable for both the patients and parents. As vomiting usually lasts for a few days one dose of ondansetron is usually enough. An oral dose is preferred because it can be easily given and can avoid the setting of an intravenous drip, which may be quite painful to the patients.

In 2008, the European Society for Pediatric Gastroenterology, Hepatology, and Nutrition and the European Society for Pediatric Infectious Diseases published an evidence-based guideline for the management of acute gastroenteritis in children in Europe. ${ }^{129}$ The statement has changed the perspective on antiemetics and comments that antiemetics may be of value for selected children with severe vomiting. However, the guideline does not clearly state the indications and rationales for choosing the different kinds of antiemetics. In the future, guidelines should concentrate more on the subgroup of patients that can benefit from the antiemetics, and which antiemetics could provide the best clinical advantages.

The essential pillars of good treatment of acute gastroenteritis always include the followings: ${ }^{130}$

i. Use of oral rehydration for dehydration;

ii. Hypotonic oral rehydration solution;

iii. Fast oral rehydration over 3 to 4 hours;

iv. Rapid realimentation with normal feeding;

v. Use of special formula is unjustified;

vi. Use of diluted formula is unjustified;

vii. Continuation of breast feeding at all time;

viii. Supplement with oral rehydration solution for ongoing losses.

The usage of antiemetic medications in selected patients may be another essential pillar.

\section{Disclosure}

The authors report no conflicts of interest relevant to this research.

\section{References}

1. by-Payne J, Elliott E. Gastroenteritis in children. Clin Evid. 2004;12:443-454

2. King CK, Glass R, Bresee JS, Duggan C. Managing acute gastroenteritis among children: oral rehydration, maintenance, and nutritional therapy. MMWR Recomm Rep. 2003;52(RR-16):1-16.

3. Santosham M. Oral rehydration therapy: reverse transfer of technology. Arch Pediatr Adolesc Med. 2002;156(12):1177-1179.

4. Glass RI, Kilgore PE, Holman RC, et al. The epidemiology of rotavirus diarrhea in the United States: surveillance and estimates of disease burden. J Infect Dis. 1996;174(Suppl 1):S5-S11.

5. Ryan MJ, Ramsay M, Brown D, Gay NJ, Farrington CP, Wall PG. Hospital admissions attributable to rotavirus infection in England and Wales. $J$ Infect Dis. 1996;(174 Suppl 1):S12-S18.
6. Carlin JB, Chondros P, Masendycz P, Bugg H, Bishop RF, Barnes GL. Rotavirus infection and rates of hospitalisation for acute gastroenteritis in young children in Australia, 1993-1996. Med J Aust. 1998;169(5):252-256.

7. Fang ZY, Yang $\mathrm{H}$, Zhang J, et al. Child rotavirus infection in association with acute gastroenteritis in two Chinese sentinel hospitals. Pediatr Int. 2000;42(4):401-405.

8. Canadian Paediatric Society. Oral rehydration therapy and early refeeding in the management of childhood gastroenteritis. Paediatr Child Health. 2006;11(8):527-531.

9. Nelson EA, Tam JS, Bresee JS, et al. Estimates of rotavirus disease burden in Hong Kong: hospital-based surveillance. J Infect Dis 2005;(192 Suppl 1):S71-S79.

10. Webb A, Starr M. Acute gastroenteritis in children. Aust Fam Physician. 2005;34(4):227-231.

11. Wilhelmi I, Roman E, Sanchez-Fauquier A. Viruses causing gastroenteritis. Clin Microbiol Infect. 2003;9(4):247-262.

12. Rivest P, Proulx M, Lonergan G, Lebel MH, Bedard L. Hospitalisations for gastroenteritis: the role of rotavirus. Vaccine. 2004;22(15-16):2013-2017.

13. Ehlken B, Laubereau B, Karmaus W, Petersen G, Rohwedder A, Forster J. Prospective population-based study on rotavirus disease in Germany. Acta Paediatr. 2002;91(7):769-775.

14. Parashar UD, Hummelman EG, Bresee JS, Miller MA, Glass RI. Global illness and deaths caused by rotavirus disease in children. Emerg Infect Dis. 2003;9(5):565-572.

15. Parashar UD, Gibson CJ, Bresse JS, Glass RI. Rotavirus and severe childhood diarrhea. Emerg Infect Dis. 2006;12(2):304-6.

16. Leung AK, Kellner JD, Davies HD. Rotavirus gastroenteritis. Adv Ther. 2005;22(5):476-487.

17. Andreasi MS, Cardoso DD, Fernandes SM, et al. Adenovirus, calicivirus and astrovirus detection in fecal samples of hospitalized children with acute gastroenteritis from Campo Grande, MS, Brazil. Mem Inst Oswaldo Cruz. 2008;103(7):741-744.

18. Caracciolo S, Minini C, Colombrita D, Foresti I, Avolio M, Tosti G, et al. Detection of sporadic cases of Norovirus infection in hospitalized children in Italy. New Microbiol. 2007;30(1):49-52.

19. Fodha I, Chouikha A, Dewar J, Trabelsi A, Boujaafar N, Steele AD. Prevalence of adenovirus antigens in children presenting with acute diarrhoea. Med Trop (Mars). 2007;67(3):256-258.

20. Jakab F, Peterfai J, Meleg E, Banyai K, Mitchell DK, Szucs G. Comparison of clinical characteristics between astrovirus and rotavirus infections diagnosed in 1997 to 2002 in Hungary. Acta Paediatr. 2005;94(6):667-671.

21. Kapikian AZ. Viral gastroenteritis. JAMA. 1993;269(5):627-630.

22. Elliott EJ. Acute gastroenteritis in children. BMJ. 2007;334(7583): 35-40.

23. Parashar UD, Alexander JP, Glass RI. Prevention of rotavirus gastroenteritis among infants and children. Recommendations of the Advisory Committee on Immunization Practices (ACIP). MMWR Recomm Rep. 2006;55(RR-12):1-13.

24. Malek MA, Curns AT, Holman RC, et al. Diarrhea- and rotavirusassociated hospitalizations among children less than 5 years of age: United States, 1997 and 2000. Pediatrics. 2006;117(6): 1887-1892.

25. Lee BP, Azimi PH, Staat MA, et al. Nonmedical costs associated with rotavirus disease requiring hospitalization. Pediatr Infect Dis $J$. 2005;24(11):984-988.

26. Chang HG, Glass RI, Smith PF, Cicirello HG, Holman RC, Morse DL. Disease burden and risk factors for hospitalizations associated with rotavirus infection among children in New York State, 1989 through 2000. Pediatr Infect Dis J. 2003;22(9):808-814.

27. Staat MA, Azimi PH, Berke T, et al. Clinical presentations of rotavirus infection among hospitalized children. Pediatr Infect Dis $J$. 2002;21(3):221-227.

28. Reis EC, Goepp JG, Katz S, Santosham M. Barriers to use of oral rehydration therapy. Pediatrics. 1994;93(5):708-711. 
29. Ozuah PO, Avner JR, Stein RE. Oral rehydration, emergency physicians, and practice parameters: a national survey. Pediatrics. 2002;109(2):259-261.

30. Walker-Smith JA, Sandhu BK, Isolauri E, et al. Guidelines prepared by the ESPGAN Working Group on Acute Diarrhoea. Recommendations for feeding in childhood gastroenteritis. European Society of Pediatric Gastroenterology and Nutrition. J Pediatr Gastroenterol Nutr. 1997;24(5):619-620.

31. Practice parameter: the management of acute gastroenteritis in young children. American Academy of Pediatrics, Provisional Committee on Quality Improvement, Subcommittee on Acute Gastroenteritis. Pediatrics. 1996;97(3):424-435.

32. World Health Organization. The treatment of diarrhoea. A manual for physicians and other senior health care workers, 4th rev edn. World Health Organization. 2005; Available from: http:/whqlibdoc.who.int/ publications/2005-9241593180.pdf.

33. Hartling L, Bellemare S, Wiebe N, Russell K, Klassen TP, Craig W. Oral versus intravenous rehydration for treating dehydration due to gastroenteritis in children. Cochrane Database Syst Rev. 2006;3:CD004390.

34. Bern C, Martines J, de Z, I, Glass RI. The magnitude of the global problem of diarrhoeal disease: a ten-year update. Bull World Health Organ. 1992;70(6):705-714.

35. Kosek M, Bern C, Guerrant RL. The global burden of diarrhoeal disease, as estimated from studies published between 1992 and 2000. Bull World Health Organ. 2003;81(3):197-204.

36. Avery ME, Snyder JD. Oral therapy for acute diarrhea. The underused simple solution. N Engl J Med. 1990;323(13):891-894.

37. Sandhu BK, Isolauri E, Walker-Smith JA, et al. A multicenter study on behalf of the European Society of Paediatric Gastroenterology and Nutrition Working Group on Acute Diarrhoea. Early feeding in childhood gastroenteritis. J Pediatr Gastroenterol Nutr. 1997;24(5): $522-527$.

38. Elliott EJ, Backhouse JA, Leach JW. Pre-admission management of acute gastroenteritis. J Paediatr Child Health. 1996;32(1): $18-21$.

39. Ford-Jones EL, Wang E, Petric M, Corey P, Moineddin R, Fearon M. Hospitalization for community-acquired, rotavirus-associated diarrhea: a prospective, longitudinal, population-based study during the seasonal outbreak. The Greater Toronto Area/Peel Region PRESI Study Group. Pediatric Rotavirus Epidemiology Study for Immunization. Arch Pediatr Adolesc Med. 2000;154(6):578-585.

40. Chow CM, Choi K, Nelson EA, et al. Use of intravenous fluids in Hong Kong children hospitalised for diarrhoea and relationship to severity and aetiology. Vaccine. 2009;27 (Suppl 5):F55-F60.

41. Bender BJ, Ozuah PO, Crain EF. Oral rehydration therapy: is anyone drinking? Pediatr Emerg Care. 2007;23(9):624-626.

42. Borison HL, Wang SC. Physiology and pharmacology of vomiting. Pharmacol Rev. 1953;5(2):193-230.

43. Freedman SB, Fuchs S. Antiemetic therapy in pediatric emergency departments. Pediatr Emerg Care. 2004;20(9):625-633.

44. Wang SC, borison HL. The vomiting center; a critical experimental analysis. Arch Neurol Psychiatry. 1950;63(6):928-941.

45. Kovac AL. Prevention and treatment of postoperative nausea and vomiting. Drugs. 2000;59(2):213-243.

46. Hockenberry-Eaton M, Benner A. Patterns of nausea and vomiting in children: nursing assessment and intervention. Oncol Nurs Forum. 1990;17(4):575-584.

47. Williams C. Causes and management of nausea and vomiting. Nurs Times. 1994;90(44):38-41.

48. Lundgren O, Peregrin AT, Persson K, Kordasti S, Uhnoo I, Svensson L. Role of the enteric nervous system in the fluid and electrolyte secretion of rotavirus diarrhea. Science. 2000;287(5452):491-495.

49. Kordasti S, Sjovall H, Lundgren O, Svensson L. Serotonin and vasoactive intestinal peptide antagonists attenuate rotavirus diarrhoea. Gut. 2004;53(7):952-957.

50. Hornby PJ. Central neurocircuitry associated with emesis. Am J Med. 2001;111( Suppl 8A):106S-112S.
51. Yates BJ, Miller AD, Lucot JB. Physiological basis and pharmacology of motion sickness: an update. Brain Res Bull. 1998;47(5): 395-406.

52. Flake ZA, Scalley RD, Bailey AG. Practical selection of antiemetics. Am Fam Physician. 2004;69(5):1169-1174

53. Spinks AB, Wasiak J, Villanueva EV, Bernath V. Scopolamine (hyoscine) for preventing and treating motion sickness. Cochrane Database Syst Rev. 2007;(3):CD002851.

54. Chisakuta AM, Mirakhur RK. Anticholinergic prophylaxis does not prevent emesis following strabismus surgery in children. Paediatr Anaesth. 1995;5(2):97-100.

55. Cubeddu LX, Trujillo LM, Talmaciu I, et al. Antiemetic activity of ondansetron in acute gastroenteritis. Aliment Pharmacol Ther. 1997;11(1):185-191.

56. Keller VE. Management of nausea and vomiting in children. J Pediatr Nurs. 1995;10(5):280-286

57. Ernst AA, Weiss SJ, Park S, Takakuwa KM, Diercks DB. Prochlorperazine versus promethazine for uncomplicated nausea and vomiting in the emergency department: a randomized, double-blind clinical trial. Ann Emerg Med. 2000;36(2): 89-94.

58. Li ST, DiGiuseppe DL, Christakis DA. Antiemetic use for acute gastroenteritis in children. Arch Pediatr Adolesc Med. 2003;157(5):475-479.

59. O'Loughlin EV, Notaras E, McCullough C, Halliday J, Henry RL. Home-based management of children hospitalized with acute gastroenteritis. J Paediatr Child Health. 1995;31(3): 189-191.

60. Nelson EA, Chow E, Lewindon PJ, Biswas R. Management of acute diarrhoea in Hong Kong. J Paediatr Child Health. 1997;33(4):360.

61. Kwon KT, Rudkin SE, Langdorf MI. Antiemetic use in pediatric gastroenteritis: a national survey of emergency physicians, pediatricians, and pediatric emergency physicians. Clin Pediatr (Phila). 2002;41(9):641-652.

62. Albano F, Bruzzese E, Spagnuolo MI, De MG. Antiemetics for children with gastroenteritis: off-label but still on in clinical practice. J Pediatr Gastroenterol Nutr. 2006;43(3):402-404.

63. Pfeil N, Uhlig U, Kostev K, et al. Antiemetic medications in children with presumed infectious gastroenteritis - pharmacoepidemiology in Europe and Northern America. J Pediatr. 2008;153(5): 659-662.

64. Cohen IT. An overview of the clinical use of ondansetron in preschool age children. Ther Clin Risk Manag. 2007;3(2):333-339.

65. Nahata MC, Hui LN, Koepke J. Efficacy and safety of ondansetron in pediatric patients undergoing bone marrow transplantation. Clin Ther. 1996;18(3):466-476.

66. Jurgens H, McQuade B. Ondansetron as prophylaxis for chemotherapy and radiotherapy-induced emesis in children. Oncology. 1992;49(4):279-285.

67. Langston WT, Wathen JE, Roback MG, Bajaj L. Effect of ondansetron on the incidence of vomiting associated with ketamine sedation in children: a double-blind, randomized, placebo-controlled trial. Ann Emerg Med 2008;52(1):30-4.

68. Scharman EJ. Use of ondansetron and other antiemetics in the management of toxic acetaminophen ingestions. J Toxicol Clin Toxicol. 1998;36(1-2):19-25.

69. Gruppo LQ, Jr. Intravenous Zofran for headache. J Emerg Med. 2006;31(2):228-229.

70. DeCamp LR, Byerley JS, Doshi N, Steiner MJ. Use of antiemetic agents in acute gastroenteritis: a systematic review and meta-analysis. Arch Pediatr Adolesc Med. 2008;162(9):858-865.

71. Stork CM, Brown KM, Reilly TH, Secreti L, Brown LH. Emergency department treatment of viral gastritis using intravenous ondansetron or dexamethasone in children. Acad Emerg Med. 2006;13(10):1027-1033.

72. Reeves JJ, Shannon MW, Fleisher GR. Ondansetron decreases vomiting associated with acute gastroenteritis: a randomized, controlled trial. Pediatrics. 2002;109(4):e62. 
73. Ramsook C, Sahagun-Carreon I, Kozinetz CA, Moro-Sutherland D. A randomized clinical trial comparing oral ondansetron with placebo in children with vomiting from acute gastroenteritis. Ann Emerg Med. 2002;39(4):397-403.

74. Freedman SB, Adler M, Seshadri R, Powell EC. Oral ondansetron for gastroenteritis in a pediatric emergency department. $N$ Engl J Med. 2006;354(16):1698-1705.

75. Roslund G, Hepps TS, McQuillen KK. The role of oral ondansetron in children with vomiting as a result of acute gastritis/gastroenteritis who have failed oral rehydration therapy: a randomized controlled trial. Ann Emerg Med. 2008;52(1):22-29.

76. Alhashimi D, Al-Hashimi H, Fedorowicz Z. Antiemetics for reducing vomiting related to acute gastroenteritis in children and adolescents. Cochrane Database Syst Rev. 2009;(2):CD005506.

77. Yilmaz HL, Yildizdas RD, Sertdemir Y. Clinical trial: Oral ondansetron for reducing vomiting secondary to acute gastroenteritis in children - a double-blind randomised study. Aliment Pharmacol Ther. 2010;31(1):82-91.

78. Bryson JC. Clinical safety of ondansetron. Semin Oncol. 1992;19(6 Suppl 15):26-32.

79. Finn AL. Toxicity and side effects of ondansetron. Semin Oncol. 1992;19(4 Suppl 10):53-60.

80. Roila F, Del FA. Ondansetron clinical pharmacokinetics. Clin Pharmacokinet. 1995;29(2):95-109.

81. Culy CR, Bhana N, Plosker GL. Ondansetron: a review of its use as an antiemetic in children. Paediatr Drugs. 2001;3(6):441-479.

82. Scuderi PE. Pharmacology of antiemetics. Int Anesthesiol Clin. 2003;41(4):41-66.

83. Forni C, Ferrari S, Loro L, et al. Granisetron, tropisetron, and ondansetron in the prevention of acute emesis induced by a combination of cisplatin-adriamycin and by high-dose ifosfamide delivered in multiple-day continuous infusions. Support Care Cancer. 2000;8(2): 131-133.

84. Orchard PJ, Rogosheske J, Burns L, et al. A prospective randomized trial of the antiemetic efficacy of ondansetron and granisetron during bone marrow transplantation. Biol Blood Marrow Transplant. 1999;5(6):386-393.

85. Karamanlioglu B, Turan A, Memis D, Sut N. Comparison of oral dolasetron and ondansetron in the prophylaxis of postoperative nausea and vomiting in children. Eur J Anaesthesiol. 2003;20(10): $831-835$

86. Olutoye O, Jantzen EC, Alexis R, Rajchert D, Schreiner MS, Watcha MF. A comparison of the costs and efficacy of ondansetron and dolasetron in the prophylaxis of postoperative vomiting in pediatric patients undergoing ambulatory surgery. Anesth Analg. 2003;97(2): 390-396.

87. Sukhani R, Pappas AL, Lurie J, Hotaling AJ, Park A, Fluder E. Ondansetron and dolasetron provide equivalent postoperative vomiting control after ambulatory tonsillectomy in dexamethasonepretreated children. Anesth Analg. 2002;95(5):1230-1235.

88. De NP, Ivani G. Management of postoperative nausea and vomiting in children. Paediatr Drugs. 2002;4(11):717-728.

89. Marill KA, Walsh MJ, Nelson BK. Intravenous Lorazepam versus dimenhydrinate for treatment of vertigo in the emergency department: a randomized clinical trial. Ann Emerg Med. 2000;36(4): 310-319.

90. McCall JE, Stubbs K, Saylors S, et al. The search for cost-effective prevention of postoperative nausea and vomiting in the child undergoing reconstructive burn surgery: ondansetron versus dimenhydrinate. J Burn Care Rehabil. 1999;20(4):309-315.

91. Schlager A, Mitterschiffthaler G, Puhringer F. Rectally administered dimenhydrinate reduces postoperative vomiting in children after strabismus surgery. Br J Anaesth. 2000;84(3):405-406.

92. Welters ID, Menges T, Graf M, Beikirch C, Menzebach A, Hempelmann G. Reduction of postoperative nausea and vomiting by dimenhydrinate suppositories after strabismus surgery in children. Anesth Analg. 2000;90(2):311-314.
93. Uhlig U, Pfeil N, Gelbrich G, et al. Dimenhydrinate in children with infectious gastroenteritis: a prospective, RCT. Pediatrics. 2009;124(4):e622-e632.

94. Tibbs RC. A clinical comparison of rectal pyrilamine maleate and trimethobenzamide hydrochloride for the control of vomiting in children. J Miss State Med Assoc. 1969;10(4):130-132.

95. Hickson GB, Altemeier WA, Clayton EW. Should promethazine in liquid form be available without prescription? Pediatrics. 1990;86(2):221-225

96. Cote CJ, Karl HW, Notterman DA, Weinberg JA, McCloskey C. Adverse sedation events in pediatrics: analysis of medications used for sedation. Pediatrics. 2000;106(4):633-644.

97. Starke PR, Weaver J, Chowdhury BA. Boxed warning added to promethazine labeling for pediatric use. $N$ Engl J Med. 2005;352(25):2653

98. Leung AK, Robson WL. Acute gastroenteritis in children: role of antiemetic medication for gastroenteritis-related vomiting. Paediatr Drugs. 2007;9(3):175-184.

99. Van EM, Dhondt F, Heck E, Ameryckx L, Van RH. A double-blind comparison of domperidone and metoclopramide suppositories in the treatment of nausea and vomiting in children. Postgrad Med $J$. 1979;55(Suppl 1):36-39.

100. Casteels-Van DM, Jaeken J, Van der SP, Van den BP. Dystonic reactions in children caused by metoclopramide. Arch Dis Child. 1970;45(239):130-133.

101. Batts KF, Munter DW. Metoclopramide toxicity in an infant. Pediatr Emerg Care. 1998;14(1):39-41.

102. Langford JS, Sheikh S. An adolescent case of sulfhemoglobinemia associated with high-dose metoclopramide and $\mathrm{N}$-acetylcysteine Ann Emerg Med. 1999;34(4 Pt 1):538-541.

103. Madani S, Tolia V. Gynecomastia with metoclopramide use in pediatric patients. J Clin Gastroenterol. 1997;24(2):79-81.

104. Wilson CM, Bird SG, Bocash W, Yang LL, Merritt RJ. Methemoglobinemia following metoclopramide therapy in an infant. J Pediatr Gastroenterol Nutr. 1987;6(4):640-642.

105. Blanc VF, Ruest P, Milot J, Jacob JL, Tang A. Antiemetic prophylaxis with promethazine or droperidol in paediatric outpatient strabismus surgery. Can J Anaesth. 1991;38(1):54-60.

106. Fassoulaki A, Galanaki E. The antiemetic effect of droperidol: is it dose dependent? Acta Anaesthesiol Belg. 1989;40(3):179-182.

107. Verheecke G, Troch E. Oral droperidol for premedication in children. Acta Anaesthesiol Belg 1985 Dec;36(4):421-6.

108. Olutoye O, Watcha MF. Management of postoperative vomiting in pediatric patients. Int Anesthesiol Clin. 2003;41(4):99-117.

109. Joshi PT, Hamel L, Joshi AR, Capozzoli JA. Use of droperidol in hospitalized children. J Am Acad Child Adolesc Psychiatry. 1998;37(2):228-230.

110. Bailey P, Norton R, Karan S. The FDA droperidol warning: is it justified? Anesthesiology. 2002;97(1):288-289.

111. Nuttall GA, Eckerman KM, Jacob KA, et al. Does low-dose droperidol administration increase the risk of drug-induced QT prolongation and torsade de pointes in the general surgical population? Anesthesiology. 2007;107(4):531-536.

112. Jacoby JL, Fulton J, Cesta M, Heller M. After the black box warning: dramatic changes in ED use of droperidol. Am J Emerg Med 2005;23(2):196.

113. Dhondt F, Traen S, VanEygen M, Baran D, Willaert H. Domperidone (R-33812) suppositories: an effective antiemetic agent in diverse pediatric conditions: multicenter trial. Curr Ther Res Clin Exp. 1978;24(8):912-923.

114. Extrapyramidal reactions due to domperidone. Lancet 1980;2(8198):802.

115. Weaving A, Bezwoda WR, Derman DP. Seizures after antiemetic treatment with high dose domperidone: report of four cases. $\mathrm{Br} \mathrm{Med}$ $J$ (Clin Res Ed). 1984;288(6432):1728

116. Bonuccelli U, Nocchiero A, Napolitano A, et al. Domperidone-induced acute dystonia and polycystic ovary syndrome. Mov Disord. 1991;6(1):79-81. 
117. Lankamp DJ, Willemse J, Pikaar SA, van Heyst AN. Prochlorperazine in childhood: side-effects. Clin Neurol Neurosurg. 1977;80(4):264-271.

118. Ordog GJ, Vann PW, Owashi ND, Wasserberger J, Herman LS, Balasubramaniam S. Intravenous prochlorperazine for the rapid control of vomiting in the emergency department. Ann Emerg Med. 1984;13(4):253-258.

119. Bardfeld PA. A controlled double-blind study of trimethobenzamide, prochlorperazine, and placebo. JAMA. 1966;196(9):796-798.

120. Drotts DL, Vinson DR. Prochlorperazine induces akathisia in emergency patients. Ann Emerg Med. 1999;34(4 Pt 1):469-475.

121. Olsen JC, Keng JA, Clark JA. Frequency of adverse reactions to prochlorperazine in the ED. Am J Emerg Med. 2000;18(5):609-611.

122. Baker FM, Cook P. Compazine complications: a review. J Natl Med Assoc. 1981;73(5):409-412.

123. Bejar JM. Compazine-induced dyskinesia in a 14-month-old boy. Clin Neuropharmacol. 1984;7(2):171-172.

124. Ginsburg CM, Clahsen J. Evaluation of trimethobenzamide hydrochloride (Tigan) suppositories for treatment of nausea and vomiting in children. J Pediatr. 1980;96(4):767-769.
125. FDA halts sales of some anti-vomiting suppositories ... and are cough medications effective in children? Child Health Alert. 2007;25:1-2.

126. Sanger GJ, Andrews PL. Treatment of nausea and vomiting: gaps in our knowledge. Auton Neurosci. 2006;129(1-2):3-16.

127. Markman M, Sheidler V, Ettinger DS, Quaskey SA, Mellits ED. Antiemetic efficacy of dexamethasone. Randomized, double-blind, crossover study with prochlorperazine in patients receiving cancer chemotherapy. N Engl J Med. 1984;311(9):549-552.

128. Gavagan T, Schumann SA. This antiemetic may help kids skip that trip to the hospital. J Fam Pract. 2009;58(2):85-88.

129. Guarino A, Albano F, Ashkenazi S, et al. European Society for Paediatric Gastroenterology, Hepatology, and Nutrition/European Society for Paediatric Infectious Diseases evidence-based guidelines for the management of acute gastroenteritis in children in Europe. J Pediatr Gastroenterol Nutr. 2008;46(Supp1 2):S81-S122.

130. Szajewska H, Hoekstra JH, Sandhu B. Management of acute gastroenteritis in Europe and the impact of the new recommendations: a multicenter study. The Working Group on acute Diarrhoea of the European Society for Paediatric Gastroenterology, Hepatology, and Nutrition. J Pediatr Gastroenterol Nutr. 2000;30(5):522-527.

\section{Publish your work in this journal}

Clinical and Experimental Gastroenterology is an international, peerreviewed, open access journal, publishing all aspects of gastroenterology in the clinic and laboratory, including: Pathology, pathophysiology of gastrointestinal disease; Investigation and treatment of gastointestinal disease; Pharmacology of drugs used in the alimentary tract;
Immunology/genetics/genomics related to gastrointestinal disease. This journal is indexed on CAS. The manuscript management system is completely online and includes a very quick and fair peer-review system. Visit http://www.dovepress.com/testimonials.php to read real quotes from published authors.

Submit your manuscript here: http://www.dovepress.com/clinical-and-experimental-gastroenterology-journal 